Review

\title{
TRPV6 as A Target for Cancer Therapy
}

\author{
John M. Stewart ${ }^{\bowtie}$ \\ Soricimed Biopharma Inc. 18 Botsford Street, Moncton, NB, Canada, E1C 4W7 \\ $\triangle$ Corresponding author: jstewart@soricimed.com. Soricimed Biopharma Inc.,18 Botsford Street, Suite 201, Moncton, NB, Canada, E1C 4W7. Tel: 1-506-856-0400. \\ Fax: 1-506-856-0414 \\ (C) The author(s). This is an open access article distributed under the terms of the Creative Commons Attribution License (https://creativecommons.org/licenses/by/4.0/). \\ See http://ivyspring.com/terms for full terms and conditions.
}

Received: 2018.11.19; Accepted: 2019.05.05; Published: 2020.01.01

\begin{abstract}
Two decades ago a class of ion channels, hitherto unsuspected, was discovered. In mammals these Transient Receptor Potential channels (TRPs) have not only expanded in number (to 26 functional channels) but also expanded the view of our interface with the physical and chemical environment. Some are heat and cold sensors while others monitor endogenous and/or exogenous chemical signals. Some TRP channels monitor osmotic potential, and others measure cell movement, stretching, and fluid flow. Many TRP channels are major players in nociception and integration of pain signals. One member of the vanilloid sub-family of channels is TRPV6. This channel is highly selective for divalent cations, particularly calcium, and plays a part in general whole-body calcium homeostasis, capturing calcium in the gut from the diet. TRPV6 can be greatly elevated in a number of cancers deriving from epithelia and considerable study has been made of its role in the cancer phenotype where calcium control is dysfunctional. This review compiles and updates recent published work on TRPV6 as a promising drug target in a number of cancers including those afflicting breast, ovarian, prostate and pancreatic tissues.
\end{abstract}

Key words: TRPV6, calcium, cancer, prostate, breast, pancreas.

\section{Background}

\section{Transient Receptor Potential Channels}

It is rare that a discovery opens an unexpected and unsuspected window on how animals, including humans, interact with their physical and chemical environments. A revolution in understanding the interface between animals and environment (external, extra-tissue, extracellular) began with the discovery in Drosophila melanogaster [1, 2] of what are now called the transient receptor potential channels. This discovery was rapidly followed by reports of a transient receptor potential channel in mammals $[3,4]$ that resembled the vanilloid receptor (VR1) reported earlier [5]. Since then this mammalian ion channel superfamily has expanded to include 26 functional members in six subfamilies: TRPC (canonical), TRPA (ankyrin), TRPML (mucolipin), TRPM (melastatin), TRPP (polycystin) and TRPV (vanilloid) [6-9].

Gradual appreciation of TRP channels can be traced through review articles that act as milestones in understanding their physiological function [6, 9-19], regulation by associated proteins [20-22], evolution [23], intracellular trafficking [24, 25], pre-mRNA splicing [26], and interactions with immune cells [27]. Monographs of the TRP field have also appeared [28-31]. The last specific review of the role of TRPV6 in cancer was published in 2012 [32] with reference to cancer in reviews of larger scope [23, 33, 34]. This review summarizes recent work on TRPV6 as it emerges as a therapeutic target in solid cancers derived from epithelia.

\section{Transient Receptor Potential Vanilloid channels}

The vanilloid sub-family of TRP (TRPV) channels comprises six members, TRPV1 to TRPV6. The first four channels are related in sequence (average homology about 45\% [35]) and are activated variously by heat, acid, stretching/osmotic strain, and certain exogenous chemicals (e.g. capsaicin), and also 
play roles in nociception and pain signal integration $[8,9]$, and thermoregulation [36]. Although related by sequence homology to the first four channels ( 35\%)[35], TRPV5 and TRPV6 have greater sequence homology to each other (81\%) [35], and show significantly different channel properties than the 'sensory' channels. TRPV5 and TRPV6 are more selective for calcium ion $\left(\mathrm{P}_{\mathrm{Ca}} / \mathrm{P}_{\mathrm{Na}} \sim 100\right)$ compared to the other four TRPVs $\left(\mathrm{P}_{\mathrm{Ca}} / \mathrm{P}_{\mathrm{Na}} \sim 1\right.$ to $\left.\sim 15\right)$, show minimal, if any, voltage or heat dependence, and are constitutively active $[8,37]$. The major function of these TRPV5 and TRPV6 at the whole organism level appears to be coarse calcium homeostasis. In mice TRPV5 is expressed predominantly in the kidney where it reclaims calcium from the pre-urine stream [38] at the level of the distal tubules. TRPV6 is predominant in the gastro-intestinal tract where it has a role in calcium import, initiating the process by importing calcium ion through the apical membrane $[3,39,40]$. The homeostatic role of the two calcium-sensitive channels in human renal intestinal and tissues has been reviewed [41].

\section{TRPV6 protein in normal human tissues}

TRPV6 protein has been reported variously in placenta, salivary gland, prostate, pancreas, testes, liver and lung but not without great inconsistency. This is not surprising considering that a reliable antibody to TRPV6 is not commercially available. Healthy human prostate produces very little, if any, TRPV6 [42, 43]. Human lung tissue appears to produce low levels of TRPV6 protein as shown in isolated lung epithelial cells [44, 45]. TRPV6 protein is produced in human placenta $[46,47]$, and the protein shows up-regulation in human endometrium during the menstrual cycle [48] and the later stages of pregnancy when fetal bone mineralization occurs [46]. Human duodenum expresses TRPV6 mRNA but TRPV6 protein was not examined [49, 50]. TRPV6 protein was not detected in human liver [40]. Salivary gland shows TRPV6 mRNA [43] and the protein was detected in the basolateral membrane of acinar cells [51]. Many of these works corroborate the earlier immunohistochemical detection of TRPV6 in esophageal epithelia, and the small and large intestine, the exocrine pancreas with weak staining in the acinar cells [40]. This latter work also indicated there was TRPV6 staining of ductal epithelia of breast and sweat gland and that in all cases staining was considerably weaker than in malignancies of the examined tissues.

Supplementary Table S1 shows a compendium of RNA-Seq data from four studies [52] [53, 54] [55] that report the amount of TRPV6 mRNA (in Transcript Per Million, TPM) that encompassed 296 subjects and, in total, 91 putatively healthy tissues. Excerpted from this Supplementary Table S1 are those tissues and studies that showed TPM values greater than 0.5, the cut-off point for these experiments for (minimally) triplicate determinations (Table 1). These data can be found at the Expression Atlas Database (www.ebi.ac.uk) (https://www.ebi.ac.uk/gxa/ experiments/) where expression is considered as low (0.5 to 10 TPM), medium (11 to $1000 \mathrm{TPM}$ ) and high (>1000 TPM). The median expression values, with few exceptions, are wildly different across the four studies. The largest value is $56 \mathrm{TMP}$ (for prostate) but this tissue is also reported as 0 TPM and 17 TPM. Nevertheless, it is clear that the expression of TRPV6 mRNA is low is most tissues. The most consistent result was for pancreas, even though the amounts are not large (10 TPM, 0 TPM, 24 TPM and 26 TPM). For comparison, in esophagus mRNA levels of TRPV6 and two common calcium-binding proteins (S100A11, Calmodulin 1) show 2 TPM, 2997 TPM and 343 TPM as median values respectively [52] and $\beta$-actin shows 3724 TPM when TRPV6 is 3 TPM [55].

Immunohistological data for TRPV6 protein in tissues are not as available as mRNA data and, as expected, more difficult to quantify and report. The Human Protein Atlas (www.proteinatlas.org) reports protein expression for assorted human tissues. For TRPV6 staining a polyclonal rabbit antibody (registry number AB-2684885) was used. This antibody is cited as 'Approved' out of a ranking sequence of Enhanced, Supported, Approved and Uncertain so results must be interpreted in this light, particularly given the database cites this antibody as "partly consistent with gene/protein characterization data". Table 2 has been excerpted from the Human Protein Atlas database to provide a comparison to tissue-specific TRPV6 mRNA in cancers illustrated in Figure 2. To appreciate the difficulty in scoring the IHC staining Supplementary Figure S1 illustrates Not Detected, Low, Medium and High ranking for some tissues. The only tissue to produce a ranking of High TRPV6 was placenta that is very dynamic and dependent on the stage of pregnancy [46].

Studies with TRPV6 knock-out mice highlighted the involvement of this channel in calcium homeostasis [56] producing defective intestinal $\mathrm{Ca}^{+2}$ absorption, reduced fertility, and increased urinary calcium. A key role for TRPV6 in male fertility and maturation of sperm in murine models with non-functional or excised TRPV6 has been reported $[57,58]$ and show decreased calcium, mediated by TRPV6, is required for sperm maturation in the lumen of the epididymis. 
Table 1: RNA-Seq data for TRPV6 mRNA in normal human tissues excerpted from Supplementary Table 1.

\begin{tabular}{|c|c|c|c|c|}
\hline & \multicolumn{4}{|c|}{ Experimental Accession Number } \\
\hline & $\begin{array}{l}\text { E-MTAB-2 } \\
836[52]\end{array}$ & $\begin{array}{l}\text { E-MTAB-3358 } \\
\text { http://fantom. } \\
\text { gsc.riken.jp/5/ }\end{array}$ & $\begin{array}{l}\text { E-MTAB- } \\
4344[53]\end{array}$ & $\begin{array}{l}\text { E-MTAB- } \\
5214 \text { [55] }\end{array}$ \\
\hline Tissue & $\begin{array}{l}\text { Median } \\
(\mathrm{N}=122)\end{array}$ & $\begin{array}{l}\text { Median } \\
(\mathrm{N}=96)\end{array}$ & $\begin{array}{l}\text { Median } \\
(\mathrm{N}=25)\end{array}$ & $\begin{array}{l}\text { Median } \\
(\mathrm{N}=53)\end{array}$ \\
\hline & TPM & TPM & TPM & TPM \\
\hline $\begin{array}{l}\text { Brodmann (1909) area } \\
24\end{array}$ & & & & 2 \\
\hline Brodmann (1909) area 9 & & & & 3 \\
\hline $\begin{array}{l}\text { C1 segment of cervical } \\
\text { spinal cord }\end{array}$ & & & & 4 \\
\hline Breast & & 0 & & 1 \\
\hline Caudate nucleus & & & & 2 \\
\hline Cerebral cortex & 2 & 0 & & 3 \\
\hline Endocervix & & & & 0.6 \\
\hline Esophagus mucosa & & & & 3 \\
\hline Esophagus & 2 & 0 & & \\
\hline Gall Bladder & 23 & 0 & & \\
\hline Hippocampus proper & & & & 0.6 \\
\hline Minor Salivary Gland & & 0 & & 5 \\
\hline Nucleus Accumbens & & 0 & & 1 \\
\hline Occipital Lobe & & 2 & & \\
\hline Ovary & 0.2 & 0.5 & 0 & 0 \\
\hline Pancreas & 10 & 0 & 24 & 26 \\
\hline Penis & & 4 & & \\
\hline Pituitary Gland & & 0 & & 0.6 \\
\hline Placenta & 17 & 0 & & \\
\hline Prostate & 56 & 0 & & 17 \\
\hline Putamen & & & & 2 \\
\hline Saliva-secreting gland & 37 & 0 & & \\
\hline Small Intestine & 0.2 & & 16 & \\
\hline Stomach & 2 & & & 3 \\
\hline Substantia Nigra & & & 0 & 1 \\
\hline Suprapubic Skin & & 0 & & 8 \\
\hline Testes & 1 & & 0.7 & 2 \\
\hline Thyroid Gland & 3 & & & 1 \\
\hline Urinary Bladder & 1 & 0 & & 2 \\
\hline Vagina & & 0 & & 2 \\
\hline Zone of Skin & 13 & & & \\
\hline
\end{tabular}

\section{Structure of the TRPV6 channel}

A flood of data published recently gives a clearer picture of the complex 3-D structures of the TRPV family of channels. Recent papers from Sobolevski's group at Columbia University have outlined the architectural elegance of the homotetrameric structures, along with information on the ion pore structure. First was an X-ray crystal structure for modified rat TRPV6 in 2016 [59]. Following quickly were rat [60] and human TRPV6 structures [61] by cryo-EM. The earlier rat X-ray structure was corrected after domain swapping between monomer units was uncovered [62]. Further studies of the pore structure followed [61, 63] and further emphasized the importance of the calcium gating function of the aspartate (D541) residue reported earlier [64]. These major accomplishments have now been extended to the first structure for the only remaining unsolved TRPV channel, TRPV3 [65]. These structures join the previous reports for TRPV1
[66], TRPV2 [67, 68], TRPV4 [69] and TRPV5 [70]. The structure of slightly modified human TRPV6 (code 6BO9) [61] is shown in the series of images in Figure 1 accessed through the RCSB Protein Data Bank (www.rcsb.org). With insight from this collection of molecular structures we can reasonably expect advances in molecules designed to modulate the activities of TRPV ion channels. For example, the promiscuous TRPV modulator 2-APB (2aminoethoxydiphenyl borate) has been modeled to a binding site in TRPV6 for which it is an inhibitor [60] and to a TRPV3 site where it is an agonist [65]. Econazole, an inhibitor of a number of ion channels [71] including TRP channels has been modeled to a binding site on this TRPV5 [70]. One common point of these identified binding sites is that they access the 'top' face of the channel and as such would not likely effect channels in the gut that face the lumen where calcium ions (and other divalent ions) are captured.

Table 2: Ranking IHC of normal human tissues for TRPV6 staining (Human Protein Atlas: www.proteinatlas.org). ND indicates Not Done.

\begin{tabular}{lll}
\hline Tissue & Cell Type & TRPV6 IHC Ranking \\
\hline Breast & Adipocyte & Low \\
& Glandular Cells & ND \\
& Myoepithelial cells & Low \\
Eolon & Glanduliar Cells & Medium \\
& & ND \\
Duodenum & & ND \\
Epididymis & & Low \\
Liver & Pneumocytes & ND \\
Lung & Stroma Cells & Low \\
Ovary & & ND \\
Pancreas & Decidual cells & High \\
Placenta & Trophoblastic cells & ND \\
& & ND \\
Prostate & & ND \\
Salivary Gland & & Medium \\
Seminal Vesicle & & ND \\
Small Intestine & & ND \\
Spleen & & Medium \\
Testes & & Medium \\
& Leydig Cells &
\end{tabular}

\section{Calcium and cancer}

Calcium plays a central role in development and maintenance of cancer phenotypes. Elevated cellular calcium as well as microcrystals of calcium salts in cancer cells are linked to malignancies and metastasis in breast cancers [72, 73]. Temporal, spatial and/or amplitudinal alterations of internal calcium concentrations influence gene transcription, tumourigenesis, cell proliferation, metastasis and susceptibility to apoptosis [74-76]. Calciumdependent remodeling of the tumour microenvironment influences angiogenesis, tumour progression and recruitment of macrophages [77]. The 
centrality of calcium in cancer can be seen in the multiple roles of the calcium-binding protein sorcin and its role in angiogenesis, migration, apoptosis, multidrug resistance and invasion [78]. Recent reviews of targeting calcium signaling in cancer therapy emphasize TRPV6 activity $[79,80]$. All these linkages of calcium to various aspects of the cancer phenotype implicate TRPV6.

\section{TRPV6 as an oncochannel}

The over-expression of TRPV6 mRNA and protein has been reported in a number of human malignancies [14, 81]. TRPV6 has been classified as an oncochannel [82] and its gene as an oncogene [32, 83, 84] although there is no evidence expression of TRPV6 itself can induce cancer or proto-oncogenes [85]. An early report showed high TRPV6 mRNA in a colorectal cancer cell line (SW480), a human chronic myelogenous leukemia cell line (K-562) $[86,87]$ and rat leukemia cells [88]. Up-regulation of TRPV6 mRNA was shown in prostate cancer [43] and in prostate cancer cell lines LNCaP and PC3 [89]. It should be noted that expression of TRPV6 in PC3 and DU145 cells in vitro appears to be inconsistent. In prostate tumours, a positive correlation between the Gleason score and TRPV6 mRNA has been reported
[87]. Immunohistochemistry of TRPV6 in healthy and malignant tissues showed low (if any) levels of protein in healthy exocrine tissues (e.g. mammary gland, pancreas, prostate) but elevated amounts in breast, colon, ovary, prostate and thyroid carcinomas [40]. Correlations of TRPV6 over-expression and Gleason scores extended to extra-prostatic extensions [42] and a role for TRPV6 in predicting prostate malignancies was suggested as TRPV6-positive tumours often invade extra-prostate tissues [90, 91] with a poor prognosis. The exact role of TRPV6 in cancer proliferation is not clear, but calcium-dependent proliferation of cancer cells was linked directly to TRPV6 [92].

Breast cancer also shows increased TRPV6 mRNA and has been reported to be $2-15$-fold greater in breast cancer when compared to healthy tissue [93, 94]. TRPV6 protein was elevated more in invasive tumour areas over non-invasive tumour areas in 93.3\% of biopsies [94]. Elevated TRPV6 was reported in estrogen receptor-negative breast cancers, and correlated to poor prognosis [95]. Reducing TRPV6 production with siRNA in breast (T-47D) [93], and prostate cancer cell lines (LNCaP) [96] resulted in decreased cell proliferation and increased apoptosis.

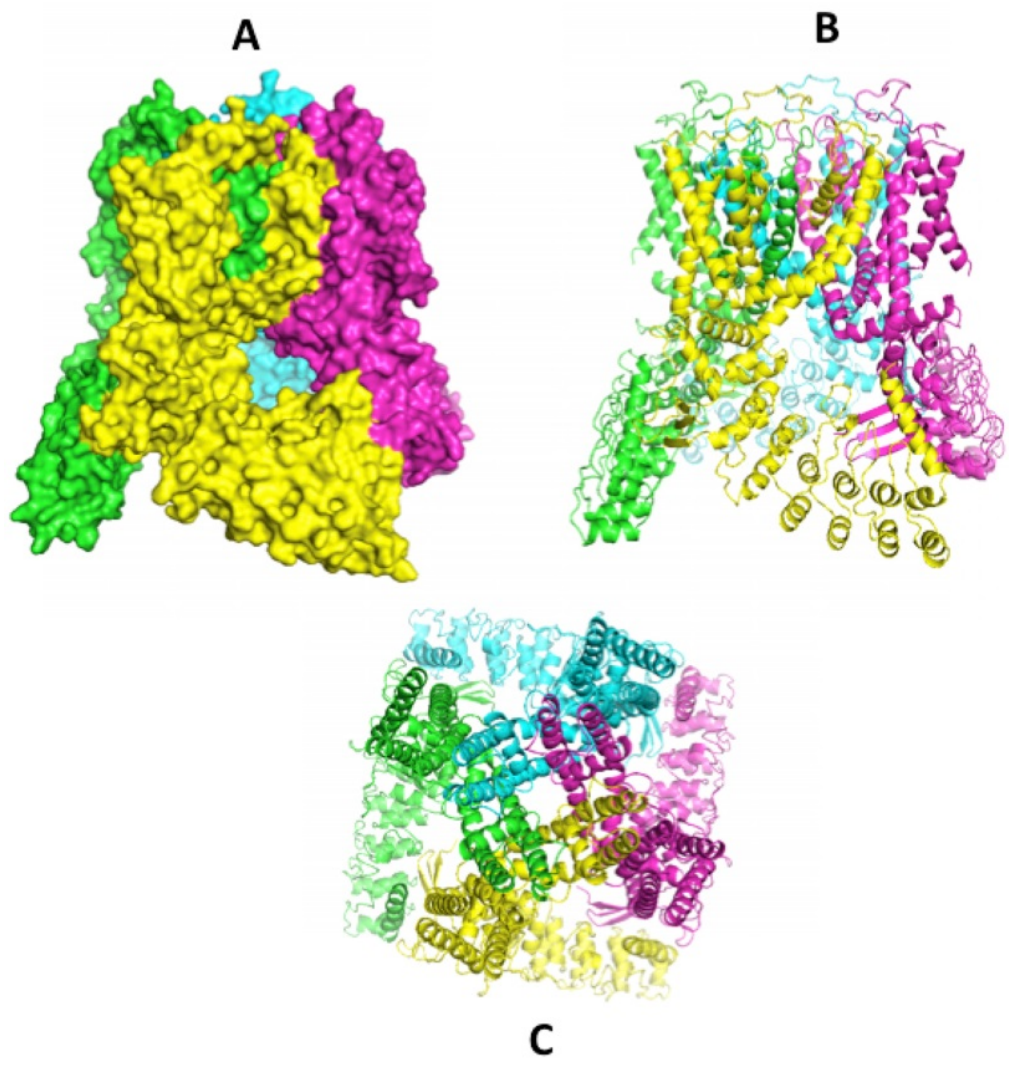

Figure 1: Structures of hTRPV6 determined by cryo-EM in nano-disks (ref 61) [61]. Image A (space filled) and B (ribbon) show a side view with monomer units in different colours clearly showing the domain swapping of helices S5-S6 of a 'preceding' monomer seen in green against the yellow focus monomer and the yellow S5-S6 interacting with the 'following' purple monomer. The bottom image (C) shows the top view, looking down the axis of the ion pore. Structures can be accessed at the RCSB Protein Data Base (www.rcsb.org) code 6BO9 [61]. 


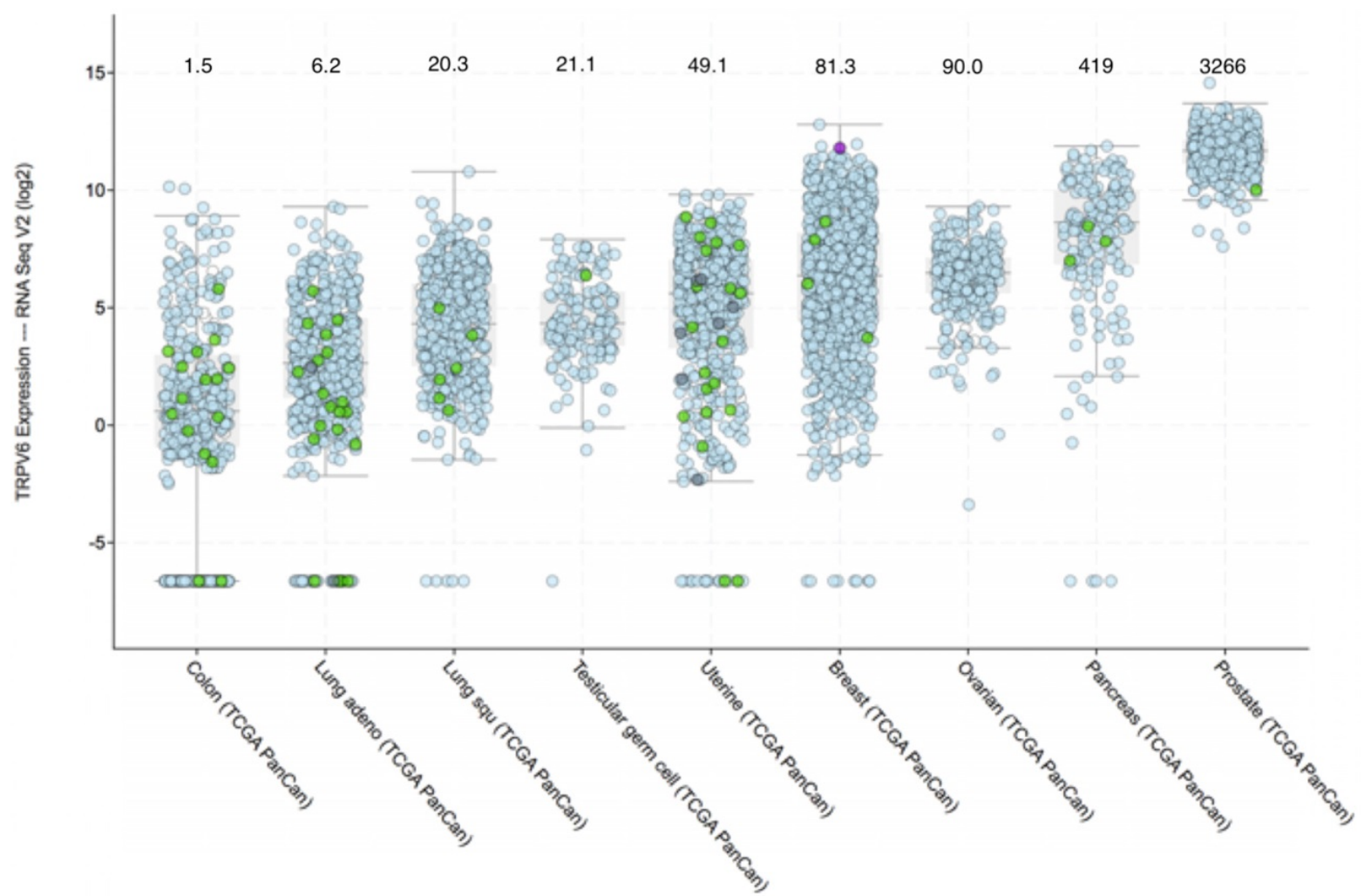

Figure 2: Prevalence of TRPV6 mRNA expression in various tumours according to the TCGA Pan-Cancer database. Cancer types are sorted by median value of fold change over healthy tissue. RNA-SEQ expression data were extracted from the cBioPortal (www.cbioportal.org) [165, 166]. Quantitation of TRPV6 mRNA expression was done using the RNA-SEQ next generation sequencing. Results are in log 2 scale meaning that +1 is up regulated $(21=$ two-fold $)$ compared to normal samples of each study. Values that are less than 0 indicate down regulation. The colour and form of each dot represent the mutational status of TRPV 6 gene as given in the figure. Median values for fold change above normal tissue can be estimated from the interactive graphic constructed by the database and are as follows and are shown above the cancer type: The full cancer descriptions, in order of appearance from left to right are: Colon adenocarcinoma; Lung adenocarcinoma; Lung squamous carcinoma; Testicular germ cell carcinoma; Uterine Corpus Endometrial Carcinoma; Breast invasive adenocarcinoma; Ovarian serous cystadenocarcinoma; Pancreatic adenocarcinoma; Prostate adenocarcinoma.

This calcium channel plays a role in gastrointestinal cancers particularly at early stages. TRPV6 mRNA is at very low levels (if at all) in late stage tumours (Stage III and IV) while $66 \%$ of Stage I tumours, and $17 \%$ of Stage II tumours show the channel over expressed [97]. There is a report that capsaicin treatment leads to TRPV6-dependent apoptosis in a gastric adenocarcinoma cell line (AGS) because of increased intracellular calcium [98]. Perhaps this result is because of a gross increase in calcium (instead of increased calcium transients) that could lead to calcium toxicity and activation of the apoptotic circuit. This effect may be confounded by the discovery of viral infection of AGS (ATCC CRL-1739) by parainfluenza type 5 (PIV5) as reported by the ATCC after its discovery [99] in AGS where the virus resulted in increased degradation of STAT1.

Figure 2 shows the expression of TRPV6 mRNA in various solid cancers. Ovarian, prostate and pancreatic cancers are particularly noted because a large proportion of the tumors $(>90 \%)$ consistently express TRPV6 mRNA well above normal levels.

Ovarian cancer was cited in an early study as over-producing TRPV6 protein in one biopsy [40], but only recently was a survey of the five different types of ovarian cancer (low grade serous, high grade serous, clear cell, endometrioid, mucinous) reported [100]. As always, care should be taken in assessing reported amounts of TRPV6 protein since there is often difficulty with available antibodies. Elevated TRPV6 mRNA was reported in early and late stages of all five of the disease types classified under the umbrella of ovarian cancer when compared to healthy tissue. Immunohistochemical detection of TRPV6 protein in tissue microarrays for ovarian cancers likewise showed elevated protein in all cancer types and at early and late stages of the diseases with little (if any) in biopsies of healthy tissue. Targeting TRPV6 with TRPV6-specific, antagonistic peptides reduced growth of SKOV-3 tumour xenografts in mice [100] further supporting this channel as a viable target. TRPV6-binding peptides delivered a conjugated fluorescent label to TRPV6-rich xenografts of human ovarian cancer (SKOV-3) and prostate cancer (DU 145), and superparamagnetic nanoparticles to SKOV-3 tumours suggesting the diagnostic photo-imaging and MRI-imaging potential of this over-expressed channel [101]. 
TRPV6 was recently implicated directly in development and prognosis of pancreatic cancer with decreased survival in patients with elevated tumour TRPV6 protein levels [102]. Reducing TRPV6 protein production in pancreatic cell lines with siRNA reduced proliferation and invasion, and initiated apoptosis and cell cycle arrest [102]. In a Phase I clinical trial of a peptide inhibitor of TRPV6 activity two patients with advanced pancreatic cancers showed tumour reduction (one by $-27 \%$ by RECIST criteria) with one patient showing $55 \%$ decrease in the validated pancreatic cancer biomarker CA19-9 [103]. Of the 23 patients enrolled in this study with cancers classed as "TRPV6-rich" $>50 \%$ showed stable disease after two courses of treatment with no drug-related serious adverse events.

TRPV6 has been reported down regulated in some cancers. Cervical squamous cell carcinoma, in early stages, showed decreased levels of TRPV6 mRNA and protein [104]. In 145 resected non-small cell lung cancer patients, decreased TRPV6 protein levels were reported as associated with shorter median survival times [105]. Esophageal squamous cell carcinoma patients showed down regulated TRPV6 mRNA and protein but with no correlation between these changes and disease specific survival (DSS) although for a short, 3-year DSS there was a small negative effect with male patients and a positive effect with female patients [106]. It is too early to know if such decreases in TRPV6 are a result of or involved in the development and progression of squamous cell neoplasms.

\section{Mechanism of action of TRPV6 as an oncochannel}

Elevated TRPV6 and subsequent sustained increases in cytosolic calcium activates the nuclear factor of activated T-cells (NFAT) transcription factors in cell lines of prostate [96] and breast cancers [93]. In these studies reduction of TRPV6 expression with silencing RNA reduced proliferation and increased apoptosis. Over-expression of TRPV6, which is constitutively active, results in a sustained elevation of intracellular calcium, which is required for activation of the calmodulin/calcineurin/NFAT pathway. The short half-life of dephosphorylated NFAT in the nucleus ( 15 - $20 \mathrm{~min})[107,108]$ requires consistent elevated cytosolic calcium to create what has been interpreted as a survival response against cell death, or a mechanism to decode calcium oscillation into a build-up of dephosphorylated NFAT in the cytoplasm [109]. While the response in each cancer type would be specific to that cancer, cell line etc. because of a different cohort of accessory transcription factors and other proteins that could interact with NFAT, the literature provides a general outline for a mechanism of action.

A target of $\mathrm{Ca}^{+2} /$ calmodulin-activated calcineurin (a phosphatase) is NFAT, a hyperphosphorylated transcription factor that is activated by dephosphorylation [110]. The role of NFAT in regulating the cell cycle and apoptosis was reviewed recently [111] as has its role in cancer [112]. Activated NFAT translocates to the nucleus [113] where it modulates a number of genes in partnership with Jun/Fos and other proteins. Activated genes influence proliferation and migration and include Membrane Type 1 Matrix Metalloproteinase and Matrix Metalloproteinase-type 2 [114], and autotaxin [115, 116]. Autotaxin is a secreted phospholipase that produces lysophosphatidyl choline, a ligand of a Growth Factor Receptor and lysophosphatidic acid receptor 1 [117]. The reported anti-apoptotic nature of increased TRPV6 may results from increased production of Bcl-2, an anti-apoptotic protein that inhibits the release of cytochrome $c$ from mitochondria and prevents apoptosome formation [118]. As well, hydroxyapatite microcrystals common in such nodularized tumours, presumably because of increased calcium influx, up regulate MMPs [73]. This simplistic signalling pathway description would be much more complicated because of four NFAT isoforms (excluding a calcineurin-independent one), a plethora of genes that are regulated and modulated by NFAT [111] and about 30 other proteins with which NFAT can partner in transcription complexes [111]. The roles of NFATs in cancer development and as a potential therapeutic target have been reviewed [112, 119-122].

A detailed study of the involvement of TRPV6 in a number of prostate cancer cell lines showed increased trafficking of TRPV6 to the plasma membrane, dependent on the Orai1 protein of the Store-Operated Calcium Channel [85]. Accompanying increased TRPV6 trafficking was increased cell proliferation, reduced apoptosis and greater cisplatin resistance [85]. With this clearer focus on the molecular details, these authors suggest TRPV6 activity is a survival response of at least three prostate cancer cell lines (LNCaP, PC-3 and DU 145) implicating a sensitivity to and requirement of increased intracellular calcium transients compared to normal tissue in the cancer phenotype. While the literature provides hints of the role of TRPV6-related elevation of intracellular calcium in the oncology phenotype and, conversely, what its inhibition might do, downstream effects of TRPV6 inhibition on cancer cell signalling pathways and gene expression are just beginning to emerge. Using siRNA to knock down TRPV6 expression in the capan-2 cell line model of 
pancreatic cancer resulted in significant decrease in Bcl-2 (B-cell lymphoma 2, apoptosis inhibitor) and increase in BAX (Bcl-2-associated $X$ protein, a promoter of apoptosis) which, taken together, indicate activation apoptosis [123]. Additionally, significant decreased MMP9 expression (matrix metalloproteinase 9) suggests decreased metastasis, and decreased PCNA expression (Proliferating cell nuclear antigen) suggests decreased DNA synthesis; the observed significant increase in calciumdependent E-cadherin expression may play a role in cell-cell interaction.

\section{Control of TRPV6 expression}

It is now well established that a number of epithelial type cancers over-express TRPV6 mRNA and likely overproduce protein compared to healthy tissues. How the TRPV6 gene becomes over expressed is not known. There is much work to do in this area but some influences are summarized below.

\section{Involvement of Vitamin D and p38 $\alpha^{\mathrm{MAPK}-14}$ in TRPV6 expression}

Vitamin D (D3) activates the production of TRPV6 ion channel. The VDR (Vitamin D receptor, a nuclear receptor) bearing Vitamin $\mathrm{D}$ binds to response elements on the TRPV6 gene, activating transcription [124]. VDR is an obligate heterodimer with retinoic acid receptor alpha in its active form [125]. More than 1000 Vitamin D Response Elements have been noted across the human genome $[126,127]$ and 3000 across the murine genome [127] providing for very complicated signalling and cross signalling. But, the role of Vitamin D is complicated further since TRPV6 also has a reciprocal role in how Vitamin D3 influences cancer [128].

Recently, a closer view of this has emerged revealing another factor involved in the Vitamin D-influenced increase TRPV6 transcription. Vitamin $\mathrm{D}$ also activates the transcription of GADD $45 \alpha$ (Growth arrest and DNA damage-inducible protein alpha) that is also produced in response to either DNA damage or stressed growth arrest conditions [126]. GADD45 $\alpha$ activates MEKK4 (Mitogen Activated Protein kinase kinase kinase) that in turn activates p38 $\alpha$ (aka CSBP2 or MAPK-14 $\alpha$ ) and JNK (c-Jun N-terminal kinase). While p38 $\alpha$, a $38 \mathrm{kD}$ protein kinase activated by phosphorylation, is produced in response to cell stress, it also enhances Vitamin D-dependent TRPV6 transcription beyond Vitamin D alone [126]. Inflammatory cytokines (e.g. IL-6) can activate p38 $\alpha$ that, by phosphorylating histone-3, contributes to the chromatin relaxation status [129], potentially allowing for greater access to TRPV6 gene. On the other hand, p38 $\alpha$ has been referred to as a tumour suppressor [130] although it has been connected to proliferation in a number of cancer cell lines such as breast cancer [131, 132], chondrosarcoma [133], prostate neoplasms [134], melanoma [135] and a number of others including HeLa cells [136].

Activated JNK inhibits NFAT4 (NFATc3) and NFATc2 (NFAT1) thus allowing for greater apoptotic activity [126], presumably by phosphorylating c-Jun and reducing formation (or activity) of the NFAT/c-Jun/Fos complex on DNA. The latter is unclear since phosphorylated c-Jun has been reported as more active in some studies [137]. For cancer cells, it is possible enhanced TRPV6 production could counteract reduced NFAT activity. A recent review of p38 $\alpha$ pathways has been published [129] summarizing these interactions.

Factors in addition to Vitamin D can also be expected to influence TRPV6 expression. In Vitamin D Receptor null, pregnant mice, TRPV6 was depressed, but in pregnant VDR-null mice duodenal TRPV6 mRNA increased about 13-fold [138].

While Vitamin D and TRPV6 have been linked to various pathologies arising from calcium deployment, the most familiar effect is that of bone metabolism and in particular osteoporosis [13]. It is interesting then that TRPV6 inhibitors can also reduce bone resorption in models of osteoporosis [139].

\section{TRPV6 transcription is regulated by other nuclear receptors}

The control of TRPV6 production by androgen receptor (AR) was first reported in LNCaP cells [96]. While providing evidence that downstream signalling from elevated calcium concentration is through the NFAT system, these authors showed that knocking down AR with siRNA resulted in decreases in TRPV6 mRNA by $48 \mathrm{~h}$ and TRPV6 protein by $72 \mathrm{~h}$ post treatment. The authors suggest $A R$ is a co-regulator of TRPV6 transcription rather than having a direct role. The role of AR in TRPV6 was cited again in terms of antagonist and agonist of the receptor [32] where dihydrotestosterone, an AR agonist, inhibits TRPV6 expression while an AR antagonist (bicalutamide) increases TRPV6 expression [89, 140, 141]. As well, androgen treatment of LNCaP decreases TRPV6 mRNA by $80 \%$ in one day [89]. In androgen sensitive prostate cell line LNCaP, TRPV6 expression has also been reported to be sensitive to $A R$, but in a ligand-independent manner [96]. While the presence of an androgen response element in the $5^{\prime}$ flanking region of the TRPV6 gene was suggested [142] there are no supporting data, but there may be a 'tier two' Androgen Receptor response element that is intergenic and at position $-13,232$ of the TRPV6 gene 
[143].

Estrogen receptor (ER) has been linked to TRPV6 expression through a response element in the gene [144]. Tamoxifen, an estrogen receptor antagonist, resulted in down regulation of TRPV6 mRNA in breast cancer cell line T-47D while estrogen increased it, as did progesterone and estradiol [93]. Estrogen-dependent up regulation of TRPV6 in breast and prostate cancer has also been reviewed and suggested to act in concert with other transcription factors that are activated by elevated calcium [142]. During rat pregnancy both uterine and placental levels of TRPV6 are up regulated by progesterone receptor and estrogen receptor dependent pathways, and is decreased by antagonists to these receptors [145].

Another nuclear receptor, Peroxisomal Proliferator Activated Receptor alpha (PPAR $\alpha$ ), has a response element on the TRPV6 gene [146] although any effects of its ligands (polyunsaturated fatty acids, endocannabinoids, fibrates) on TRPV6 status are not known. There may be a link between PPAR $\alpha$, endocannabinoids such as anandamide and TRPV channels, including TRPV6, during oxidative stress [147]. Since PPAR $\alpha$, like Vitamin D, also requires dimer formation with retinoic acid receptor $\alpha$, it provides for an interesting question of the links of retinoids and fatty acids to cancer.

\section{TRPV6 expression regulated by transcription factors}

There are a large number of binding sites for transcription factors (TF) in the promoter region of TRPV6 gene [148]. The list of curated transcription factors cited by this database contains HOXA5 MAZ, NKX2-1, PPARA, TLX2, and ZEB1. Uncurated associations of TFs regulating trpv6 expression from this site, and using known binding site sequences comprise GATA1, GLI2, HNF1A, KLF13, MTF1, NFE2, NR5A2, RBPJ, and VDR. None of the transcription factors listed has been reported in the literature as affecting trpv6 expression with the exception of VDR and PPAR $\alpha$, while AR and ER, missing from the database entry, have been (see above). All of the transcriptions factors listed above have been implicated in some aspect of the oncologic process.

\section{Location: TRPV6 expression in tumours varies with cell location.}

Expression of TRPV6 mRNA and protein depend on the local environment of the cell and, in tumours, cell position. In a study of 140 prostate tumours TRPV6 was strongly expressed in those tumour cells in contact with the stroma, and strong band-like patterns were seen were the cells were in contact with the normal tissue [42]. This locational production of TRPV6 was also reported in a study of other prostate tumours [90] and to a degree in prostate cancer cells [85]. In breast cancers, tumour staining for TRPV6 protein revealed a more general staining throughout the lesion but with more intense staining on the margins in contact with normal tissue [94]. In this latter study there was greater TRPV6 expression $(3-4 \mathrm{X})$ in smaller $(\leq 2 \mathrm{~cm})$ than in larger $(>2 \mathrm{~cm})$ Stage I breast tumours, but about the same in both size categories of Stage III tumours and showed particular concentration of the channel in invasive regions. As a word of caution for work with cancer cell lines, the level of expression of TRPV6 may increase with both time in culture and passage number as observed in equine chondrocytes where TRPV6 increased 4-fold over 3 passages [149].

\section{Gene copy number}

Over expression of TRPV6 may result from amplification of the number of TRPV6 genes. Normally there should be a copy number of 2, but TRPV6 gene amplification has been reported in breast cancer cell lines and biopsies [95]. An examination of genetic data on the www.cbioportal.org database for gene amplification in each of the cancer types listed in Figure 2 showed amplification of the TRPV6 gene was not a common occurrence. The rate of gene amplification was less than $1 \%$ of cancers in Figure 2 except for ovarian serous cystadenocarcinoma (1.7\%) and prostate adenocarcinoma (1.0\%). Overall the incidence of TRPV6 gene amplification was 33 gene duplications in 4,517 tumours $(0.7 \%)$ and thus, is not likely a common cause of TRPV6 expression changes.

The cbioportal database (www.cbioportal.org) can be used to determine whether TRPV6 gene copy number correlates with increased TRPV6 mRNA. For breast adenocarcinoma $(\mathrm{n}=1020, \mathrm{r}=-0.06)$ and pancreatic adenocarcinoma $(n=184, r=-0.09)$ there are no statistically significant Pearson's correlations. On the other hand, ovarian cystadenocarcinoma $(\mathrm{n}=$ $585, \mathrm{r}=0.29, \mathrm{p}<0.001$ ) and prostate adenocarcinoma ( $\mathrm{n}=494, \mathrm{r}=0.36, \mathrm{p}<0.001)$ showed statistically significant correlation between TRPV6 mRNA and TRPV6 gene copy number. Thus, the case is mixed whether amplification leads to greater TRPV6 mRNA transcription.

\section{Gain/Loss-of-function mutations leading to pathology}

There has been one putative gain-of-function TRPV6 mutation reported and connected to pathology [150]. This mutation, consisting of three, non-synonymous polymorphisms (C157R; M378V; 
and M681T) had significantly greater representation in renal calcium stone patients than in non-stone forming patients. This single report of pathology in an ancestral homozygotic is surprising considering the low levels (if any) of TRPV6 protein in human kidney. This mutation, initially reported in the seminal publication of human TRPV6 gene [43] was also reported as an ancestral type [151]. The TRPV6 sequence from one patient homozygous for the ancestral haplotype was expressed in Xenopus eggs and showed double the calcium permeability compared to the derived haplotype [150]. On the other hand the channel expressed in HEK293 showed no statistical difference between calcium conductance and other parameters [152]. There are a number of SNPs reported $[43,150]$ but none have been linked to increased TRPV6 function or a disease state. In fact, the two expressed proteins TRPV6a (R157, V378, T681) and TRPV6b (C157, M378, M681) showed no difference in the frequency of expression in prostate cancer patients [153] indicating TRPV6 alleles have no differential influence on prostate cancer.

Work is beginning to emerge on pathologies from loss-of-function mutations of TRPV6. A maternally inherited, heterozygous, missense mutant (G660R) and a paternally inherited, non-sense mutant (R510Ter) resulted in severe interference in mineralization of the fetal skeleton [154]. Transient neonatal hyperparathyroidism with associated difficulties in maternal-fetal calcium transport has been reported for loss-of-function mutations including a frame-shift mutation, three missense mutations and a combined frame-shift plus intronic mutation that altered mRNA splicing [155].

\section{Additional Factors}

Mature TRPV6 is heavily N-glycosylated [156] but exists in a few major forms: a fully glycosylated ion channel and an ion channel with modified or absent oligosaccharide. TRPV5 and TRPV6 expressed in HEK293 cells are activated by fluid flow and removal of the glycan from TRPV5 resulted in loss of this phenomenon [157]. Klotho, a $\beta$-glucuronidase linked to ageing, is believed to play a part in initiating the deglycosylation of TRPV5 and TRPV6 [158]. Removal of sialic acid residues capping the oligosaccharide attached to TRPV5 by Klotho increases its residence time in the membrane [159] through interaction with galectin [159]. Treatment with a Klotho also causes increased calcium flux in TRPV6 [160, 161]. Silencing Klotho produced no change in TRPV6 expression in bone marrow-derived dendritic cells [162]. The role of Klotho in cancer is not clear since it has been reported as down regulated in breast cancer [163], up regulated in ovarian cancer
[158], and both up and down regulated in various hepatocellular cancers [163]. The glycosylation status of TRPV6 tetramers may play a role in the overall 3D structure of those TRPV and may also influence what channel modulators can do to the channels and to where on the channel they bind. Constitutively active, TRPV6 may offer an opportunity to study the effect of glycation on large polymeric protein complexes, carrying as it does its own built-in monitor (calcium influx).

\section{Pharmacology of TRPV6}

TRPV6 has emerged as a target in cancer treatment because of its role in increasing intracellular calcium and initiating downstream signalling pathways that increase cell proliferation, metastasis and inhibition of apoptosis. As such, TRPV6 joins the list of ion channels that are being targeted for cancer treatment. A review of pharmacological approaches to exploiting TRP channel activity in cancer has been published [164] and a number of TRPV6 inhibitors are cited in a recent review of targeting calcium signalling in cancer [79]. A peptide inhibitor of TRPV6 (SOR-C13) completed a Phase I clinical safety trial [103] and has been shown to reduce growth in cell and animal models ovarian and prostate cancers [100, 101]. Table 3 summarizes the public literature for inhibitors of TRPV6 and TRPV5.

\section{Summary}

TRPV6 is clearly a valid target to disrupt further the aberrant calcium homeostasis observed in and required by many cancers. Reduction of TRPV6 activity by decreasing expression of the channel or by pharmacological intervention has shown efficacy in four cancer types: adenocarcinomas of breast, ovarian, prostate and pancreas. The evidence for the utility of TRPV6 inhibition in solid cancers has built over the last number of years in cancer cell lines, in xenograft murine models, and now has a suggestion of efficacy in humans. Whether targeting TRPV6 with antibodies or antibody drug conjugates, peptide inhibitors or peptide drug conjugates, or new chemical entities informed by 3-D structural analysis, there is a path forward to exploit the over production of TRPV6 to our benefit. The key issues to be resolved for a successful antagonist of TRPV6 are: an $\mathrm{IC}_{50}$ low enough to be clinically meaningful (i.e., required dose), specificity in inhibiting only TRPV6, low human toxicity, bio-stability, and cost. Still, it is unclear how the expression of TRPV6 gene and production of protein is up regulated in these cancers and that may offer another route to exploit TRPV6. 
Table 3: Summary of compounds that inhibit TRPV5 and/or TRPV6. Abbreviations: LNCaP \& PC-3-prostate cancer cell lines; VG = voltage gated; 2 -APB = 2-aminoethyl-diphenylborate; IP3 = Inositol 1,4,5-triphosphate; SERCA = Sarcoplasmic/Endoplasmic Reticulum $\mathrm{Ca}^{+2}$-ATPase; Orai $=$ protein component of Calcium Release Activated Channel (CRAC); SOCE = Store Operated Calcium Entrance channel; cyt P450 = cytochrome P450; MTD = Maximum Tolerated Dose.

\begin{tabular}{|c|c|c|c|c|c|}
\hline Compound & TRPV6 IC $50(\mu \mathrm{M})$ & $\begin{array}{l}\text { TRPV5 } \\
\text { IC }_{50}(\mu \mathrm{M})\end{array}$ & Other targets \& comments & $\begin{array}{l}\text { Efficacy/ } \\
\text { Toxicology }\end{array}$ & Clinical Development \\
\hline Ruthenium Red & $9[167,168]$ & 0.12 [168] & $\begin{array}{l}\text { N-type VG Calcium channels [169]; TRPV2 [170]; in } \\
\text { thapsigargin negative experiments, inhibition of Ca } \\
\text { is only } 60 \% \text { [171]; not bound to pore [167]. } \\
\text { Suppresses CRACs [172] }\end{array}$ & Neurotoxic [169] & None reported \\
\hline TH-1177 & $675[173]$ & $456[173]$ & $\begin{array}{l}\mathrm{IC}_{50}=3.2 \mu \mathrm{M} \text { in LNCaP \& } 17 \mu \mathrm{M} \text { in PC-3 [174]. } \\
\text { T-type VG Calcium channels [175]; TRPC1 [176] }\end{array}$ & None in mice at $180 \mathrm{mg} / \mathrm{kg}$ [174] & None reported \\
\hline $\begin{array}{l}\text { TH-117 best } \\
\text { derivative }\end{array}$ & 90 [173] & $503[173]$ & Other TRP channels [173] & No information, & None reported \\
\hline 2-APB & 20.7 [177] & No data & $\begin{array}{l}\text { CRAC channel IC50 = } 10 \text { uM [178]. IP3 receptor, } \\
\text { SERCA, Orai, various TRP channels [177]. TRPV6 } \\
\text { inhibition is allosteric [60] }\end{array}$ & $\begin{array}{l}\text { rapid hydrolysis \& } \\
\text { transesterification [177] }\end{array}$ & None reported \\
\hline $\begin{array}{l}\text { 2-APB derivative } \\
22 \mathrm{~b}\end{array}$ & $5[177]$ & No data & SOCE, $\mathrm{IC}_{50}=2.8 \mu \mathrm{M}[177]$ & $\begin{array}{l}\text { Inhibits CRAC channels essential } \\
\text { to T-cells at } 10 \mathrm{mM} \text { [178] }\end{array}$ & None reported \\
\hline Econazole & $201[173]$ & $\begin{array}{l}442[173] \\
{[168]}\end{array}$ & $\begin{array}{l}\text { Cyt P450 [179]; VG Calcium channels, [179]; receptor } \\
\text { operated Calcium channels [71] }\end{array}$ & $\begin{array}{l}\text { Broad-spectrum antifungal } \\
\text { agent.[180] }\end{array}$ & $\begin{array}{l}\text { Commercial antifungal: } \\
\text { Spectrazole (USA), } \\
\text { Ecostatin (Canada) }\end{array}$ \\
\hline $\begin{array}{l}\text { Miconazole } \\
\text { (monistat) }\end{array}$ & $201[173]$ & $442[173]$ & TRPV4 [181]; cyt P450 inhibitor [182] & Antifungal agent[180] & $\begin{array}{l}\text { Commercial antifungal: } \\
\text { Monistat, Micatin }\end{array}$ \\
\hline $\begin{array}{l}\text { Piperazine } \\
\text { derivative Cis-22a }\end{array}$ & 0.32 [183] & $2.4[183]$ & TRPV1, TRPV3, TRPV5, TRPM8, SOCE [183] & $\begin{array}{l}\text { In vitro growth inhibition of } \\
\text { TRPV6-containing cell line T } \\
47 \mathrm{D}[183]\end{array}$ & None reported \\
\hline Capsaicin & $\begin{array}{l}\text { Estimated as } \\
\text { between } 25 \mathrm{uM} \text { and } \\
50 \mathrm{uM} \text { for apoptosis } \\
\text { from Figure } 1 \text { of [98] }\end{array}$ & Not tested & $\begin{array}{l}\text { Inhibits TRPV6 in human SCLC and increases } \\
\text { apoptosis in vitro and decreases murine xenografts } \\
\text { [45]. Increases apoptosis in gastric cancer cells [98]. }\end{array}$ & $\begin{array}{l}\text { Well-recognized activator of } \\
\text { TRPV1 heat sensor. }\end{array}$ & None reported \\
\hline $\begin{array}{l}\Delta^{9} \text {-tetrahydro- } \\
\text { cannabivarin } \\
(\mathrm{THCV})\end{array}$ & $9.4[184]$ & $4.8[184]$ & $\begin{array}{l}\text { TRPV5, TRPV6 inhibition [184]; } \\
\text { Agonist to TRPV3 and TRPV4 [185]; Activated } \\
\text { TRPV1, TRPA1, TRPV2 [186]. }\end{array}$ & None reported & None reported \\
\hline $\begin{array}{l}\text { SOR-C13 } \\
\text { (13 amino acid } \\
\text { peptide) }\end{array}$ & $0.014[101]$ & No effect & Reduces ovarian tumour xenografts [100]. & $\begin{array}{l}\text { No drug-related serious adverse } \\
\text { clinical events, no MTD } \\
\text { determined, safe to } 6.2 \mathrm{mg} / \mathrm{kg} \\
{[103]}\end{array}$ & $\begin{array}{l}\text { Completed Phase Ia } \\
\text { clinical trial [103] }\end{array}$ \\
\hline Lidocaine & $\begin{array}{l}\text { Not done but from } \\
\text { viability graphs } \sim 5 \\
\mathrm{mM}[187]\end{array}$ & Not Done & $\begin{array}{l}\text { Reduced cell invasion and migration of } \\
\text { MDA-MB-231, PC-3 and ES-2 cells. [187] }\end{array}$ & None reported & None reported. \\
\hline
\end{tabular}

\section{Abbreviations}

TRPV6: Transient Receptor Potential Vanilloid 6; TRPV5: Transient Receptor Potential Vanilloid 5; VR1: vanilloid receptor 1; TRPA: Transient Receptor Potential Ankyrin; TRPC: Transient Receptor Potential Canonical; TRPM: Transient Receptor Potential Melastatin; TRPML: Transient Receptor Potential Mucolipin; TRPP: Transient Receptor Potential Polycystin; TPM: Transcripts Per Million; cryo-EM: Cryogenic electron microscopy; 2-ABP: 2Aminoethoxydiphenyl borate; RECIST: Response Evaluation Criteria in Solid Tumors; NSCLC: Non-small cell lung cancer; DSS: disease specific survival; NFAT: nuclear factor of activated T-cells; Bcl-2: B-cell lymphoma 2; MMPs: matrix metalloproteinases; VDR: Vitamin D Receptor; GADD45a: Growth arrest and DNA damage-inducible protein alpha; MEKK4: Mitogen Activated Protein kinase kinase kinase; JNK: c-Jun N-terminal kinase; IL-6: interleukin 6; AR: Androgen Receptor; PPARa Peroxisomal Proliferator Activated Receptor alpha: PPARa; ER: Estrogen Receptor.

\section{Supplementary Material}

Supplementary figures and tables. http://www.jcancer.org/v11p0374s1.pdf

\section{Acknowledgements}

The author gratefully acknowledges the contributions of the Research and Development team at Soricimed Biopharma Inc. for their unwavering dedication to the work of the TRPV6 project: Dr. Dominique Dugourd, VP, R\&D; Senior Scientists in alphabetical order Michelle Davies, Tyler Lutes, and Christopher Rice.

\section{Conflict of Interest}

JMS is a founder, a shareholder and member of the Board of Directors of Soricimed Biopharma Inc. Additionally, JMS, as Chief Scientific Officer, led the discovery of soricidin and TRPV6-inhibiting peptides derived from it. 


\section{References}

1. Minke B: Drosophila mutant with a transducer defect. Biophys Struct Mech 1977, 3(1):59-64.

2. Montell C, Rubin GM: Molecular characterization of the Drosophila trp locus: a putative integral membrane protein required for phototransduction. Neuron 1989, 2(4):1313-1323.

3. Hoenderop JG, van der Kemp AW, Hartog A, van de Graaf SF, van Os CH, Willems PH, Bindels RJ: Molecular identification of the apical Ca2+ channel in 1, 25-dihydroxyvitamin D3-responsive epithelia. I Biol Chem 1999, 274(13):8375-8378

4. Peng JB, Chen XZ, Berger UV, Vassilev PM, Tsukaguchi H, Brown EM, Hediger MA: Molecular cloning and characterization of a channel-like transporter mediating intestinal calcium absorption. J Biol Chem 1999, 274(32):22739-22746.

5. Caterina MJ, Schumacher MA, Tominaga M, Rosen TA, Levine JD, Julius D: The capsaicin receptor: a heat-activated ion channel in the pain pathway. Nature 1997, 389(6653):816-824

6. Pedersen SF, Owsianik G, Nilius B: TRP channels: an overview. Cell Calcium 2005, 38(3-4):233-252.

7. Venkatachalam K, Montell C: TRP channels. Annu Rev Biochem 2007, 76:387-417.

8. Gees M, Colsoul B, Nilius B: The role of transient receptor potential cation channels in Ca2+ signaling. Cold Spring Harb Perspect Biol 2010, 2(10):a003962.

9. Wu LJ, Sweet TB, Clapham DE: International Union of Basic and Clinical Pharmacology. LXXVI. Current progress in the mammalian TRP ion channel family. Pharmacol Rev 2010, 62(3):381-404.

10. Hoenderop JG, Bindels RJ: Epithelial Ca2+ and $\mathrm{Mg} 2+$ channels in health and disease. J Am Soc Nephrol 2005, 16(1):15-26.

11. Minke B: TRP channels and Ca2+ signaling. Cell Calcium 2006, 40(3):261-275.

12. Nilius B, Voets T: TRP channels: a TR(I)P through a world of multifunctional cation channels. Pflugers Arch 2005, 451(1):1-10.

13. Suzuki Y, Landowski CP, Hediger MA: Mechanisms and regulation of epithelial Ca2+ absorption in health and disease. Annu Rev Physiol 2008, 70:257-271.

14. Wissenbach U, Niemeyer BA: Trpv6. Handb Exp Pharmacol 2007(179):221-234.

15. Hoenderop JG, Bindels RJ: Calciotropic and magnesiotropic TRP channels. Physiology (Bethesda) 2008, 23:32-40.

16. van Goor MKC, Hoenderop JGJ, van der Wijst J: TRP channels in calcium homeostasis: from hormonal control to structure-function relationship of TRPV5 and TRPV6. Biochim Biophys Acta 2017, 1864(6):883-893.

17. Smani T, Shapovalov G, Skryma R, Prevarskaya N, Rosado JA: Functional and physiopathological implications of TRP channels. Biochim Biophys Acta 2015, 1853(8):1772-1782

18. Stoerger C, Flockerzi V: The transient receptor potential cation channel subfamily V member 6 (TRPV6): genetics, biochemical properties, and functions of exceptional calcium channel proteins. Biochem Cell Biol 2014, 92(6):441-448

19. Montell C: The history of TRP channels, a commentary and reflection. Pflugers Arch 2011, 461(5):499-506.

20. van de Graaf SF, Hoenderop JG, Bindels RJ: Regulation of TRPV5 and TRPV6 by associated proteins. Am J Physiol Renal Physiol 2006, 290(6):F1295-1302.

21. Singh AK, McGoldrick LL, Twomey EC, Sobolevsky AI: Mechanism of calmodulin inactivation of the calcium-selective TRP channel TRPV6. Sci Adv 2018, 4(8):eaau6088

22. Bate N, Caves RE, Skinner SP, Goult BT, Basran J, Mitcheson JS, Vuister GW: A Novel Mechanism for Calmodulin-Dependent Inactivation of Transient Receptor Potential Vanilloid 6. Biochemistry 2018, 57(18):2611-2622.

23. Fecher-Trost C, Weissgerber P, Wissenbach U: TRPV6 channels. Handb Exp Pharmacol 2014, 222:359-384.

24. Cayouette S, Boulay G: Intracellular trafficking of TRP channels. Cell Calcium 2007, 42(2):225-232.

25. Dong XP, Wang $\mathrm{X}, \mathrm{Xu} \mathrm{H}$ : TRP channels of intracellular membranes. I Neurochem 2010, 113(2):313-328

26. Vazquez E, Valverde MA: A review of TRP channels splicing. Semin Cell Dev Biol 2006, 17(6):607-617.

27. Bose $\mathrm{T}$, Cieslar-Pobuda $\mathrm{A}, \mathrm{Wiechec} \mathrm{E}$ : Role of ion channels in regulating $\mathrm{Ca}(2)(+)$ homeostasis during the interplay between immune and cancer cells. Cell Death Dis 2015, 6:e1648.

28. Siemens J, Hanack C: Modulation of TRP ion channels by venomous toxins. Handb Exp Pharmacol 2014, 223:1119-1142.

29. Kozak JA, Putney JW: Calcium entry channels in non-excitable cells. Boca Raton: Taylor \& Francis; 2017

30. Zhu MX: TRP channels. Boca Raton: CRC Press/Taylor \& Francis; 2011.

31. Liedtke WB: TRP ion channel function in sensory transduction and cellular signaling cascades. Boca Raton: Taylor \& Francis; 2007.

32. Lehen'kyi V, Raphael M, Prevarskaya N: The role of the TRPV6 channel in cancer. J Physiol 2012, 590(Pt 6):1369-1376.

33. Fecher-Trost $C$, Wissenbach $U$, Weissgerber P: TRPV6: From identification to function. Cell Calcium 2017, 67:116-122.

34. Peng JB, Suzuki Y, Gyimesi G, Hediger MA: TRPV5 and TRPV6 Calcium-Selective Channels. In: Calcium Entry Channels in Non-Excitable Cells. edn. Edited by Kozak JA, Putney JW, Jr. Boca Raton (FL); 2018: 241-274.
35. Vriens J, Owsianik G, Voets T, Droogmans G, Nilius B: Invertebrate TRP proteins as functional models for mammalian channels. Pflugers Arch 2004, 449(3):213-226.

36. Caterina MJ: Transient receptor potential ion channels as participants in thermosensation and thermoregulation. Am J Physiol Regul Integr Comp Physiol 2007, 292(1):R64-76.

37. Vennekens R, Hoenderop JG, Prenen J, Stuiver M, Willems PH, Droogmans G, Nilius B, Bindels RJ: Permeation and gating properties of the novel epithelial $\mathrm{Ca}(2+)$ channel. J Biol Chem 2000, 275(6):3963-3969.

38. Nijenhuis T, Hoenderop JG, van der Kemp AW, Bindels RJ: Localization and regulation of the epithelial Ca2+ channel TRPV6 in the kidney. J Am Soc Nephrol 2003, 14(11):2731-2740.

39. Peng JB, Brown EM, Hediger MA: Apical entry channels in calcium-transporting epithelia. News Physiol Sci 2003, 18:158-163.

40. Zhuang L, Peng JB, Tou L, Takanaga H, Adam RM, Hediger MA, Freeman MR: Calcium-selective ion channel, CaT1, is apically localized in gastrointestinal tract epithelia and is aberrantly expressed in human malignancies. Lab Invest 2002, 82(12):1755-1764.

41. van Goor MKC, Hoenderop JGJ, van der Wijst J: TRP channels in calcium homeostasis: from hormonal control to structure-function relationship of TRPV5 and TRPV6. Biochim Biophys Acta Mol Cell Res 2017, 1864(6):883-893.

42. Fixemer $\mathrm{T}$, Wissenbach $\mathrm{U}$, Flockerzi V, Bonkhoff $\mathrm{H}$ : Expression of the Ca2+-selective cation channel TRPV6 in human prostate cancer: a novel prognostic marker for tumor progression. Oncogene 2003, 22(49):7858-7861.

43. Wissenbach U, Niemeyer BA, Fixemer T, Schneidewind A, Trost C, Cavalie A, Reus K, Meese E, Bonkhoff H, Flockerzi V: Expression of CaT-like, a novel calcium-selective channel, correlates with the malignancy of prostate cancer. I Biol Chem 2001, 276(22):19461-19468.

44. Vachel L, Norez C, Jayle C, Becq F, Vandebrouck C: The low PLC-delta1 expression in cystic fibrosis bronchial epithelial cells induces upregulation of TRPV6 channel activity. Cell Calcium 2015, 57(1):38-48.

45. Lau JK, Brown KC, Dom AM, Witte TR, Thornhill BA, Crabtree CM, Perry HE, Brown JM, Ball JG, Creel RG et al: Capsaicin induces apoptosis in human small cell lung cancer via the TRPV6 receptor and the calpain pathway. Apoptosis 2014, 19(8):1190-1201.

46. Stumpf T, Zhang Q, Hirnet D, Lewandrowski U, Sickmann A, Wissenbach U, Dorr J, Lohr C, Deitmer JW, Fecher-Trost C: The human TRPV6 channel protein is associated with cyclophilin B in human placenta. J Biol Chem 2008, 283(26):18086-18098

47. Fecher-Trost C, Wissenbach U, Beck A, Schalkowsky P, Stoerger C, Doerr J, Dembek A, Simon-Thomas M, Weber A, Wollenberg P et al: The in vivo TRPV6 protein starts at a non-AUG triplet, decoded as methionine, upstream of canonical initiation at AUG. J Biol Chem 2013, 288(23):16629-16644.

48. Yang H, Choi KC, Hyun SH, Jeung EB: Coexpression and estrogen-mediated regulation of TRPV6 and PMCA1 in the human endometrium during the menstrual cycle. Mol Reprod Dev 2011, 78(4):274-282.

49. Balesaria S, Sangha S, Walters JR: Human duodenum responses to vitamin D metabolites of TRPV6 and other genes involved in calcium absorption. Am J Physiol Gastrointest Liver Physiol 2009, 297(6):G1193-1197.

50. Lameris AL, Nevalainen PI, Reijnen D, Simons E, Eygensteyn J, Monnens L, Bindels RJ, Hoenderop JG: Segmental transport of $\mathrm{Ca}(2)(+)$ and $\mathrm{Mg}(2)(+)$ along the gastrointestinal tract. Am I Physiol Gastrointest Liver Physiol 2015, 308(3):G206-216

51. Homann V, Kinne-Saffran E, Arnold WH, Gaengler P, Kinne RK: Calcium transport in human salivary glands: a proposed model of calcium secretion into saliva. Histochem Cell Biol 2006, 125(5):583-591.

52. Uhlen M, Fagerberg L, Hallstrom BM, Lindskog C, Oksvold P, Mardinoglu A, Sivertsson A, Kampf C, Sjostedt E, Asplund A et al: Proteomics. Tissue-based map of the human proteome. Science 2015, 347(6220):1260419.

53. Lin S, Lin Y, Nery JR, Urich MA, Breschi A, Davis CA, Dobin A, Zaleski C, Beer MA, Chapman WC et al: Comparison of the transcriptional landscapes between human and mouse tissues. Proc Natl Acad Sci U S A 2014, 111(48):17224-17229.

54. Abugessaisa I, Noguchi S, Hasegawa A, Harshbarger J, Kondo A, Lizio M, Severin J, Carninci P, Kawaji H, Kasukawa T: FANTOM5 CAGE profiles of human and mouse reprocessed for GRCh38 and GRCm38 genome assemblies. Sci Data 2017, 4:170107.

55. Consortium GT: Human genomics. The Genotype-Tissue Expression (GTEx) pilot analysis: multitissue gene regulation in humans. Science 2015, 348(6235):648-660

56. Bianco SD, Peng JB, Takanaga H, Suzuki Y, Crescenzi A, Kos CH, Zhuang L, Freeman $\mathrm{MR}$, Gouveia $\mathrm{CH}, \mathrm{Wu} J$ et al: Marked disturbance of calcium homeostasis in mice with targeted disruption of the Trpv6 calcium channel gene. J Bone Miner Res 2007, 22(2):274-285.

57. Weissgerber P, Kriebs U, Tsvilovskyy V, Olausson J, Kretz O, Stoerger C, Mannebach S, Wissenbach U, Vennekens R, Middendorff R et al: Excision of Trpv6 gene leads to severe defects in epididymal Ca2+ absorption and male fertility much like single D541A pore mutation. J Biol Chem 2012, 287(22):17930-17941

58. Weissgerber P, Kriebs U, Tsvilovskyy V, Olausson J, Kretz O, Stoerger C, Vennekens R, Wissenbach U, Middendorff R, Flockerzi V et al: Male fertility depends on $\mathrm{Ca}(2)+$ absorption by TRPV6 in epididymal epithelia. Sci Signal 2011, 4(171):ra27.

59. Saotome K, Singh AK, Yelshanskaya MV, Sobolevsky AI: Crystal structure of the epithelial calcium channel TRPV6. Nature 2016, 534(7608):506-511. 
60. Singh AK, Saotome K, McGoldrick LL, Sobolevsky AI: Structural bases of TRP channel TRPV6 allosteric modulation by 2-APB. Nat Commun 2018, 9(1):2465.

61. McGoldrick LL, Singh AK, Saotome K, Yelshanskaya MV, Twomey EC, Grassucci RA, Sobolevsky AI: Opening of the human epithelial calcium channel TRPV6. Nature 2018, 553(7687):233-237.

62. Singh AK, Saotome K, Sobolevsky AI: Swapping of transmembrane domains in the epithelial calcium channel TRPV6. Sci Rep 2017, 7(1):10669.

63. Sakipov S, Sobolevsky AI, Kurnikova MG: Ion Permeation Mechanism in Epithelial Calcium Channel TRVP6. Sci Rep 2018, 8(1):5715.

64. Voets T, Janssens A, Droogmans G, Nilius B: Outer pore architecture of a Ca2+-selective TRP channel. J Biol Chem 2004, 279(15):15223-15230.

65. Singh AK, McGoldrick LL, Sobolevsky AI: Structure and gating mechanism of the transient receptor potential channel TRPV3. Nat Struct Mol Biol 2018.

66. Liao M, Cao E, Julius D, Cheng Y: Structure of the TRPV1 ion channel determined by electron cryo-microscopy. Nature 2013, 504(7478):107-112.

67. Huynh KW, Cohen MR, Jiang J, Samanta A, Lodowski DT, Zhou ZH, Moiseenkova-Bell VY: Structure of the full-length TRPV2 channel by cryo-EM. Nat Commun 2016, 7:11130.

68. Zubcevic L, Herzik MA, Jr., Chung BC, Liu Z, Lander GC, Lee SY: Cryo-electron microscopy structure of the TRPV2 ion channel. Nat Struct Mol Biol 2016, 23(2):180-186.

69. Deng Z, Paknejad N, Maksaev G, Sala-Rabanal M, Nichols CG, Hite RK, Yuan P: Cryo-EM and X-ray structures of TRPV4 reveal insight into ion permeation and gating mechanisms. Nat Struct Mol Biol 2018, 25(3):252-260.

70. Hughes TET, Lodowski DT, Huynh KW, Yazici A, Del Rosario J, Kapoor A, Basak S, Samanta A, Han X, Chakrapani S et al: Structural basis of TRPV5 channel inhibition by econazole revealed by cryo-EM. Nat Struct Mol Biol 2018, 25(1):53-60.

71. Villalobos C, Fonteriz R, Lopez MG, Garcia AG, Garcia-Sancho J: Inhibition of voltage-gated $\mathrm{Ca} 2+$ entry into $\mathrm{GH} 3$ and chromaffin cells by imidazole antimycotics and other cytochrome P450 blockers. FASEB J 1992, 6(9):2742-2747.

72. Morgan MP, Cooke MM, McCarthy GM: Microcalcifications associated with breast cancer: an epiphenomenon or biologically significant feature of selected tumors? J Mammary Gland Biol Neoplasia 2005, 10(2):181-187.

73. Morgan MP, Cooke MM, Christopherson PA, Westfall PR, McCarthy GM: Calcium hydroxyapatite promotes mitogenesis and matrix metalloproteinase expression in human breast cancer cell lines. Mol Carcinog 2001, 32(3):111-117.

74. Monteith GR, McAndrew D, Faddy HM, Roberts-Thomson SJ: Calcium and cancer: targeting Ca2+ transport. Nat Rev Cancer 2007, 7(7):519-530.

75. Prevarskaya N, Skryma R, Shuba Y: Calcium in tumour metastasis: new roles for known actors. Nat Rev Cancer 2011, 11(8):609-618

76. Stewart TA, Yapa KT, Monteith GR: Altered calcium signaling in cancer cells. Biochim Biophys Acta 2015, 1848(10 Pt B):2502-2511.

77. Sang LJ, Ju HQ, Liu GP, Tian T, Ma GL, Lu YX, Liu ZX, Pan RL, Li RH, Piao HL et al: LncRNA CamK-A Regulates Ca(2+)-Signaling-Mediated Tumor Microenvironment Remodeling. Mol Cell 2018.

78. Shabnam B, Padmavathi G, Banik K, Girisa S, Monisha J, Sethi G, Fan L, Wang L, Mao X, Kunnumakkara AB: Sorcin a Potential Molecular Target for Cancer Therapy. Transl Oncol 2018, 11(6):1379-1389.

79. Cui C, Merritt R, Fu L, Pan Z: Targeting calcium signaling in cancer therapy. Acta Pharm Sin B 2017, 7(1):3-17.

80. Maly IV, Hofmann WA: Calcium and Nuclear Signaling in Prostate Cancer. Int J Mol Sci 2018, 19(4).

81. Lehen'kyi V, Prevarskaya N: Study of TRP Channels in Cancer Cells. In: TRP Channels. edn. Edited by Zhu MX. Boca Raton (FL); 2011.

82. Huber SM: Oncochannels. Cell Calcium 2013, 53(4):241-255.

83. Santoni G, Farfariello V, Amantini C: TRPV channels in tumor growth and progression. Adv Exp Med Biol 2011, 704:947-967.

84. Lehen'kyi V, Prevarskaya N: Oncogenic TRP channels. Adv Exp Med Biol 2011, 704:929-945.

85. Raphael M, Lehen'kyi V, Vandenberghe M, Beck B, Khalimonchyk S, Vanden Abeele F, Farsetti L, Germain E, Bokhobza A, Mihalache A et al: TRPV6 calcium channel translocates to the plasma membrane via Orai1-mediated mechanism and controls cancer cell survival. Proc Natl Acad Sci U S A 2014 111(37):E3870-3879.

86. Semenova SB, Vassilieva IO, Fomina AF, Runov AL, Negulyaev YA: Endogenous expression of TRPV5 and TRPV6 calcium channels in human leukemia K562 cells. Am J Physiol Cell Physiol 2009, 296(5):C1098-1104.

87. Peng JB, Chen XZ, Berger UV, Weremowicz S, Morton CC, Vassilev PM, Brown EM, Hediger MA: Human calcium transport protein CaT1. Biochem Biophys Res Commun 2000, 278(2):326-332.

88. Bodding $\mathrm{M}$, Wissenbach $\mathrm{U}$, Flockerzi V: The recombinant human TRPV6 channel functions as $\mathrm{Ca} 2+$ sensor in human embryonic kidney and rat basophilic leukemia cells. J Biol Chem 2002, 277(39):36656-36664.

89. Peng JB, Zhuang L, Berger UV, Adam RM, Williams BJ, Brown EM, Hediger MA, Freeman MR: CaT1 expression correlates with tumor grade in prostate cancer. Biochem Biophys Res Commun 2001, 282(3):729-734.

90. Wissenbach $\mathrm{U}$, Niemeyer B, Himmerkus N, Fixemer T, Bonkhoff $\mathrm{H}$, Flockerzi $\mathrm{V}$ : TRPV6 and prostate cancer: cancer growth beyond the prostate correlates with increased TRPV6 Ca2+ channel expression. Biochem Biophys Res Commun 2004, 322(4):1359-1363.

91. Thebault S, Flourakis M, Vanoverberghe K, Vandermoere F, Roudbaraki M, Lehen'kyi V, Slomianny C, Beck B, Mariot P, Bonnal JL et al: Differential role of transient receptor potential channels in $\mathrm{Ca} 2+$ entry and proliferation of prostate cancer epithelial cells. Cancer Res 2006, 66(4):2038-2047.

92. Schwarz EC, Wissenbach U, Niemeyer BA, Strauss B, Philipp SE, Flockerzi V, Hoth M: TRPV6 potentiates calcium-dependent cell proliferation. Cell Calcium 2006, 39(2):163-173

93. Bolanz KA, Hediger MA, Landowski CP: The role of TRPV6 in breast carcinogenesis. Mol Cancer Ther 2008, 7(2):271-279.

94. Dhennin-Duthille I, Gautier M, Faouzi M, Guilbert A, Brevet M, Vaudry D, Ahidouch A, Sevestre H, Ouadid-Ahidouch H: High expression of transient receptor potential channels in human breast cancer epithelial cells and tissues: correlation with pathological parameters. Cell Physiol Biochem 2011, 28(5):813-822.

95. Peters AA, Simpson PT, Bassett JJ, Lee JM, Da Silva L, Reid LE, Song S, Parat MO, Lakhani SR, Kenny PA et al: Calcium channel TRPV6 as a potential therapeutic target in estrogen receptor-negative breast cancer. Mol Cancer Ther 2012, 11(10):2158-2168.

96. Lehen'kyi V, Flourakis M, Skryma R, Prevarskaya N: TRPV6 channel controls prostate cancer cell proliferation via $\mathrm{Ca}(2+) / \mathrm{NFAT}$-dependent pathways. Oncogene 2007, 26(52):7380-7385.

97. Peleg S, Sellin JH, Wang Y, Freeman MR, Umar S: Suppression of aberrant transient receptor potential cation channel, subfamily $\mathrm{V}$, member 6 expression in hyperproliferative colonic crypts by dietary calcium. Am J Physiol Gastrointest Liver Physiol 2010, 299(3):G593-601.

98. Chow J, Norng M, Zhang J, Chai J: TRPV6 mediates capsaicin-induced apoptosis in gastric cancer cells--Mechanisms behind a possible new "hot" cancer treatment. Biochim Biophys Acta 2007, 1773(4):565-576.

99. Young DF, Carlos TS, Hagmaier K, Fan L, Randall RE: AGS and other tissue culture cells can unknowingly be persistently infected with PIV5; a virus that blocks interferon signalling by degrading STAT1. Virology 2007, 365(1):238-240.

100. Xue H, Wang Y, MacCormack TJ, Lutes T, Rice C, Davey M, Dugourd D, Ilenchuk TT, Stewart JM: Inhibition of Transient Receptor Potential Vanilloid 6 channel, elevated in human ovarian cancers, reduces tumour growth in a xenograft model. J Cancer 2018, 9(17):3196-3207.

101. Bowen CV, DeBay D, Ewart HS, Gallant P, Gormley S, Ilenchuk TT, Iqbal U, Lutes T, Martina M, Mealing G et al: In vivo detection of human TRPV6-rich tumors with anti-cancer peptides derived from soricidin. PLoS One 2013, 8(3):e58866.

102. Song H, Dong M, Zhou J, Sheng W, Li X, Gao W: Expression and prognostic significance of TRPV6 in the development and progression of pancreatic cancer. Oncol Rep 2018.

103. Fu S, Hirte H, Welch S, Ilenchuk TT, Lutes T, Rice C, Fields N, Nemet A, Dugourd D, Piha-Paul S et al: Erratum to: First-in-human phase I study of SOR-C13, a TRPV6 calcium channel inhibitor, in patients with advanced solid tumors. Invest New Drugs 2017, 35(3):397.

104. Sun F, Xiao L, Jang XX, Xiong Y, Li Q, Yue XJ, Wei YJ, Wei YX, Ma YL, Yu YH: TRPV6 is a prognostic marker in early-stage cervical squamous cell carcinoma. Tumour Biol 2016.

105. Fan H, Shen YX, Yuan YF: Expression and prognostic roles of TRPV5 and TRPV6 in non-small cell lung cancer after curative resection. Asian Pac J Cancer Prev 2014, 15(6):2559-2563.

106. Zhang SS, Xie X, Wen J, Luo KJ, Liu QW, Yang H, Hu Y, Fu JH: TRPV6 plays a new role in predicting survival of patients with esophageal squamous cell carcinoma. Diagn Pathol 2016, 11:14.

107. Konig A, Fernandez-Zapico ME, Ellenrieder V: Primers on molecular pathways--the NFAT transcription pathway in pancreatic cancer. Pancreatology 2010, 10(4):416-422.

108. Marangoni F, Murooka TT, Manzo T, Kim EY, Carrizosa E, Elpek NM, Mempel TR: The transcription factor NFAT exhibits signal memory during serial T cell interactions with antigen-presenting cells. Immunity 2013, 38(2):237-249.

109. Tomida T, Hirose $K$, Takizawa A, Shibasaki F, lino M: NFAT functions as a working memory of Ca2+ signals in decoding Ca2+ oscillation. EMBO J 2003, 22(15):3825-3832

110. Crabtree GR, Olson EN: NFAT signaling: choreographing the social lives of cells. Cell 2002, 109 Suppl:S67-79.

111. Mognol GP, Carneiro FR, Robbs BK, Faget DV, Viola JP: Cell cycle and apoptosis regulation by NFAT transcription factors: new roles for an old player. Cell Death Dis 2016, 7:e2199.

112. Shou J, Jing J, Xie J, You L, Jing Z, Yao J, Han W, Pan H: Nuclear factor of activated T cells in cancer development and treatment. Cancer Lett 2015, 361(2):174-184.

113. Masuda ES, Imamura R, Amasaki Y, Arai K, Arai N: Signalling into the T-cell nucleus: NFAT regulation. Cell Signal 1998, 10(9):599-611.

114. Saygili E, Rana OR, Meyer C, Gemein C, Andrzejewski MG, Ludwig A, Weber C, Schotten U, Kruttgen A, Weis J et al: The angiotensin-calcineurin-NFAT pathway mediates stretch-induced up-regulation of matrix metalloproteinases-2/-9 in atrial myocytes. Basic Res Cardiol 2009, 104(4):435-448.

115. Liu S, Umezu-Goto M, Murph M, Lu Y, Liu W, Zhang F, Yu S, Stephens LC, Cui $X$, Murrow $G$ et al: Expression of autotaxin and lysophosphatidic acid receptors increases mammary tumorigenesis, invasion, and metastases. Cancer Cell 2009, 15(6):539-550.

116. Mancini M, Toker A: NFAT proteins: emerging roles in cancer progression. Nat Rev Cancer 2009, 9(11):810-820. 
117. Cao P, Aoki Y, Badri L, Walker NM, Manning CM, Lagstein A, Fearon ER, Lama VN: Autocrine lysophosphatidic acid signaling activates beta-catenin and promotes lung allograft fibrosis. J Clin Invest 2017, 127(4):1517-1530.

118. Gomez J, Martinez AC, Gonzalez A, Garcia A, Rebollo A: The Bcl-2 gene is differentially regulated by IL-2 and IL-4: role of the transcription factor NF-AT. Oncogene 1998, 17(10):1235-1243.

119. Qin JJ, Nag S, Wang W, Zhou J, Zhang WD, Wang H, Zhang R: NFAT as cancer target: mission possible? Biochim Biophys Acta 2014, 1846(2):297-311.

120. Daniel C, Gerlach K, Vath M, Neurath MF, Weigmann B: Nuclear factor of activated $\mathrm{T}$ cells - a transcription factor family as critical regulator in lung and colon cancer. Int J Cancer 2014, 134(8):1767-1775.

121. Griesmann H, Ripka S, Pralle M, Ellenrieder V, Baumgart S, Buchholz M, Pilarsky C, Aust D, Gress TM, Michl P: WNT5A-NFAT signaling mediates resistance to apoptosis in pancreatic cancer. Neoplasia 2013, 15(1):11-22.

122. Pan MG, Xiong $Y$, Chen F: NFAT gene family in inflammation and cancer. Curr Mol Med 2013, 13(4):543-554.

123. Song H, Dong M, Zhou J, Sheng W, Li X, Gao W: Expression and prognostic significance of TRPV6 in the development and progression of pancreatic cancer. Oncol Rep 2018, 39(3):1432-1440.

124. Meyer MB, Watanuki M, Kim S, Shevde NK, Pike JW: The human transient receptor potential vanilloid type 6 distal promoter contains multiple vitamin D receptor binding sites that mediate activation by 1,25-dihydroxyvitamin D3 in intestinal cells. Mol Endocrinol 2006, 20(6):1447-1461.

125. Orlov I, Rochel N, Moras D, Klaholz BP: Structure of the full human RXR/VDR nuclear receptor heterodimer complex with its DR3 target DNA. EMBO J 2012, 31(2):291-300.

126. Ishizawa $\mathrm{M}$, Akagi $\mathrm{D}$, Yamamoto J, Makishima M: 1alpha,25-Dihydroxyvitamin D3 enhances TRPV6 transcription through p38 MAPK activation and GADD45 expression. J Steroid Biochem Mol Biol 2017, 172:55-61.

127. Wang TT, Tavera-Mendoza LE, Laperriere D, Libby E, MacLeod NB, Nagai $Y$, Bourdeau V, Konstorum A, Lallemant B, Zhang R et al: Large-scale in silico and microarray-based identification of direct 1,25-dihydroxyvitamin D3 target genes. Mol Endocrinol 2005, 19(11):2685-2695.

128. Lehen'kyi V, Raphael M, Oulidi A, Flourakis M, Khalimonchyk S, Kondratskyi A, Gordienko DV, Mauroy B, Bonnal JL, Skryma R et al: TRPV6 determines the effect of vitamin D3 on prostate cancer cell growth. PLoS One 2011, 6(2):e16856.

129. Cuadrado A, Nebreda AR: Mechanisms and functions of p38 MAPK signalling. Biochem J 2010, 429(3):403-417.

130. Wagner EF, Nebreda AR: Signal integration by JNK and p38 MAPK pathways in cancer development. Nat Rev Cancer 2009, 9(8):537-549.

131. Lee RJ, Albanese C, Stenger RJ, Watanabe G, Inghirami G, Haines GK, 3rd, Webster M, Muller WJ, Brugge JS, Davis RJ et al: pp60(v-src) induction of cyclin D1 requires collaborative interactions between the extracellular signal-regulated kinase, p38, and Jun kinase pathways. A role for cAMP response element-binding protein and activating transcription factor- 2 in pp60(v-src) signaling in breast cancer cells. J Biol Chem 1999, 274(11):7341-7350.

132. Neve RM, Holbro T, Hynes NE. Distinct roles for phosphoinositide 3-kinase, mitogen-activated protein kinase and p38 MAPK in mediating cell cycle progression of breast cancer cells. Oncogene 2002, 21(29):4567-4576.

133. Halawani D, Mondeh R, Stanton LA, Beier F: p38 MAP kinase signaling is necessary for rat chondrosarcoma cell proliferation. Oncogene 2004, 23(20):3726-3731

134. Ricote M, Garcia-Tunon I, Bethencourt F, Fraile B, Onsurbe P, Paniagua R, Royuela M: The p38 transduction pathway in prostatic neoplasia. J Pathol 2006, 208(3):401-407.

135. Recio JA, Merlino G: Hepatocyte growth factor/scatter factor activates proliferation in melanoma cells through p38 MAPK, ATF-2 and cyclin D1. Oncogene 2002, 21(7):1000-1008.

136. Fan L, Yang X, Du J, Marshall M, Blanchard K, Ye X: A novel role of p38 alpha MAPK in mitotic progression independent of its kinase activity. Cell Cycle 2005, 4(11):1616-1624.

137. Behrens A, Sibilia M, Wagner EF: Amino-terminal phosphorylation of c-Jun regulates stress-induced apoptosis and cellular proliferation. Nat Genet 1999, 21(3):326-329.

138. Fudge NJ, Kovacs CS: Pregnancy up-regulates intestinal calcium absorption and skeletal mineralization independently of the vitamin $\mathrm{D}$ receptor. Endocrinology 2010, 151(3):886-895.

139. Reiman A, Murguresan A: Peptides for the treatment of resporptive bone disease. European Patent Office. 2017. Publication number WO2017075702.

140. Vanden Abeele F, Roudbaraki M, Shuba Y, Skryma R, Prevarskaya N: Store-operated $\mathrm{Ca} 2+$ current in prostate cancer epithelial cells. Role of endogenous Ca2+ transporter type 1. J Biol Chem 2003, 278(17):15381-15389.

141. Bodding M, Fecher-Trost C, Flockerzi V: Store-operated Ca2+ current and TRPV6 channels in lymph node prostate cancer cells. I Biol Chem 2003, 278(51):50872-50879.

142. Gkika D, Prevarskaya N: Molecular mechanisms of TRP regulation in tumor growth and metastasis. Biochim Biophys Acta 2009, 1793(6):953-958.

143. Wilson S, Qi J, Filipp FV: Refinement of the androgen response element based on ChIP-Seq in androgen-insensitive and androgen-responsive prostate cancer cell lines. Sci Rep 2016, 6:32611.

144. Weber K, Erben RG, Rump A, Adamski J: Gene structure and regulation of the murine epithelial calcium channels ECaC1 and 2. Biochem Biophys Res Commun 2001, 289(5):1287-1294
145. Lee BM, Lee GS, Jung EM, Choi KC, Jeung EB: Uterine and placental expression of TRPV6 gene is regulated via progesterone receptor- or estrogen receptor-mediated pathways during pregnancy in rodents. Reprod Biol Endocrinol 2009, 7:49.

146. Lemay DG, Hwang DH: Genome-wide identification of peroxisome proliferator response elements using integrated computational genomics. J Lipid Res 2006, 47(7):1583-1587.

147. Gallelli CA, Calcagnini S, Romano A, Koczwara JB, de Ceglia M, Dante D, Villani R, Giudetti AM, Cassano T, Gaetani S: Modulation of the Oxidative Stress and Lipid Peroxidation by Endocannabinoids and Their Lipid Analogues. Antioxidants (Basel) 2018, 7(7).

148. Rouillard AD, Gundersen GW, Fernandez NF, Wang Z, Monteiro CD, McDermott MG, Ma'ayan A: The harmonizome: a collection of processed datasets gathered to serve and mine knowledge about genes and proteins. Database (Oxford) 2016, 2016.

149. Hdud IM, El-Shafei AA, Loughna P, Barrett-Jolley R, Mobasheri A: Expression of Transient Receptor Potential Vanilloid (TRPV) channels in different passages of articular chondrocytes. Int J Mol Sci 2012, 13(4):4433-4445.

150. Suzuki Y, Pasch A, Bonny O, Mohaupt MG, Hediger MA, Frey FJ: Gain-of-function haplotype in the epithelial calcium channel TRPV6 is a risk actor for renal calcium stone formation. Hum Mol Genet 2008, 17(11):1613-1618

151. Akey JM, Swanson WJ, Madeoy J, Eberle M, Shriver MD: TRPV6 exhibits unusual patterns of polymorphism and divergence in worldwide populations. Hum Mol Genet 2006, 15(13):2106-2113.

152. Hughes DA, Tang K, Strotmann R, Schoneberg T, Prenen J, Nilius B, Stoneking M: Parallel selection on TRPV6 in human populations. PLoS One 2008, 3(2):e1686

153. Kessler T, Wissenbach U, Grobholz R, Flockerzi V: TRPV6 alleles do not influence prostate cancer progression. BMC Cancer 2009, 9:380

154. Burren CP, Caswell R, Castle B, Welch CR, Hilliard TN, Smithson SF, Ellard S: TRPV6 compound heterozygous variants result in impaired placental calcium transport and severe undermineralization and dysplasia of the fetal skeleton. Am J Med Genet A 2018, 176(9):1950-1955.

155. Suzuki Y, Chitayat D, Sawada H, Deardorff MA, McLaughlin HM, Begtrup A, Millar K, Harrington J, Chong K, Roifman M et al: TRPV6 Variants Interfere with Maternal-Fetal Calcium Transport through the Placenta and Cause Transient Neonatal Hyperparathyroidism. Am I Hum Genet 2018, 102(6):1104-1114

156. Hirnet D, Olausson J, Fecher-Trost C, Bodding M, Nastainczyk W, Wissenbach U, Flockerzi V, Freichel M: The TRPV6 gene, cDNA and protein. Cell Calcium 2003, 33(5-6):509-518.

157. Cha SK, Kim JH, Huang CL: Flow-induced activation of TRPV5 and TRPV6 channels stimulates $\mathrm{Ca}(2+)$-activated $\mathrm{K}(+)$ channel causing membrane hyperpolarization. Biochim Biophys Acta 2013, 1833(12):3046-3053.

158. Lu L, Katsaros D, Wiley A, de la Longrais IA, Puopolo M, Yu H: Klotho expression in epithelial ovarian cancer and its association with insulin-like growth factors and disease progression. Cancer Invest 2008, 26(2):185-192.

159. Cha SK, Ortega B, Kurosu H, Rosenblatt KP, Kuro OM, Huang CL: Removal of sialic acid involving Klotho causes cell-surface retention of TRPV5 channel via binding to galectin-1. Proc Natl Acad Sci U S A 2008, 105(28):9805-9810.

160. Chang O, Hoefs S, van der Kemp AW, Topala CN, Bindels RJ, Hoenderop JG: The beta-glucuronidase klotho hydrolyzes and activates the TRPV5 channel. Science 2005, 310(5747):490-493.

161. Lu P, Boros S, Chang Q, Bindels RJ, Hoenderop JG: The beta-glucuronidase klotho exclusively activates the epithelial Ca2+ channels TRPV5 and TRPV6. Nephrol Dial Transplant 2008, 23(11):3397-3402.

162. Xuan NT, Hai NV: Changes in expression of klotho affect physiological processes, diseases, and cancer. Iran J Basic Med Sci 2018, 21(1):3-8.

163. Zhou X, Wang X: Klotho: a novel biomarker for cancer. J Cancer Res Clin Oncol 2015, 141(6):961-969.

164. Gautier M, Dhennin-Duthille I, Ay AS, Rybarczyk P, Korichneva I, Ouadid-Ahidouch $\mathrm{H}$ : New insights into pharmacological tools to TR(i)P cancer up. Br J Pharmacol 2014, 171(10):2582-2592.

165. Gao J, Aksoy BA, Dogrusoz U, Dresdner G, Gross B, Sumer SO, Sun Y, Jacobsen A, Sinha R, Larsson E et al: Integrative analysis of complex cancer genomics and clinical profiles using the cBioPortal. Sci Signal 2013, 6(269):pl1.

166. Cerami E, Gao J, Dogrusoz U, Gross BE, Sumer SO, Aksoy BA, Jacobsen A, Byrne CJ, Heuer ML, Larsson E et al: The cBio cancer genomics portal: an open platform for exploring multidimensional cancer genomics data. Cancer Discov 2012, 2(5):401-404

167. Hoenderop JG, Vennekens R, Muller D, Prenen J, Droogmans G, Bindels RI, Nilius B: Function and expression of the epithelial $\mathrm{Ca}(2+)$ channel family: comparison of mammalian ECaC1 and 2.J Physiol 2001, 537(Pt 3):747-761.

168. Nilius B, Prenen J, Vennekens R, Hoenderop JG, Bindels RJ, Droogmans G: Pharmacological modulation of monovalent cation currents through the epithelial Ca2+ channel ECaC1. Br J Pharmacol 2001, 134(3):453-462.

169. Tapia R, Velasco I: Ruthenium red as a tool to study calcium channels, neuronal death and the function of neural pathways. Neurochem Int 1997, 30(2):137-147.

170. Juvin V, Penna A, Chemin J, Lin YL, Rassendren FA: Pharmacological characterization and molecular determinants of the activation of transient receptor potential V2 channel orthologs by 2-aminoethoxydiphenyl borate. Mol Pharmacol 2007, 72(5):1258-1268. 
171. Tomilin VN, Vasil'eva IO, Marakhova, II, Neguliaev Iu A, Semenova CB: [The functional characteristics oF TRPV5 and TRPV6 channels in normal and transformed human blood lymphocytes]. Tsitologiia 2013, 55(5):300-306.

172. Prakriya M, Lewis RS: CRAC channels: activation, permeation, and the search for a molecular identity. Cell Calcium 2003, 33(5-6):311-321.

173. Landowski CP, Bolanz KA, Suzuki Y, Hediger MA: Chemical inhibitors of the calcium entry channel TRPV6. Pharm Res 2011, 28(2):322-330.

174. Haverstick DM, Heady TN, Macdonald TL, Gray LS: Inhibition of human prostate cancer proliferation in vitro and in a mouse model by a compound synthesized to block Ca2+ entry. Cancer Res 2000, 60(4):1002-1008.

175. Cove-Smith A, Mulgrew CJ, Rudyk O, Dutt N, McLatchie LM, Shattock MJ, Hendry BM: Anti-proliferative actions of T-type calcium channel inhibition in Thy1 nephritis. Am J Pathol 2013, 183(2):391-401.

176. Narayanan KL, Subramaniam S, Bengston CP, Irmady K, Unsicker K, von Bohlen und Halbach O: Role of transient receptor potential channel 1 (TRPC1) in glutamate-induced cell death in the hippocampal cell line HT22. J Mol Neurosci 2014, 52(3):425-433.

177. Hofer A, Kovacs G, Zappatini A, Leuenberger M, Hediger MA, Lochner M: Design, synthesis and pharmacological characterization of analogs of 2-aminoethyl diphenylborinate (2-APB), a known store-operated calcium channel blocker, for inhibition of TRPV6-mediated calcium transport. Bioorg Med Chem 2013, 21(11):3202-3213.

178. Prakriya M, Lewis RS: Potentiation and inhibition of $\mathrm{Ca}(2+)$ release-activated $\mathrm{Ca}(2+)$ channels by 2-aminoethyldiphenyl borate (2-APB) occurs independently of IP(3) receptors. I Physiol 2001, 536(Pt 1):3-19.

179. Kofeler HC, Fauler G, Windischhofer W, Leis HJ: Effect of cytochrome P-450 inhibitors econazole, bifonazole and clotrimazole on prostanoid formation. $\mathrm{Br}$ J Pharmacol 2000, 130(6):1241-1246.

180. Dellenbach P, Thomas JL, Guerin V, Ochsenbein E, Contet-Audonneau N: Topical treatment of vaginal candidosis with sertaconazole and econazole sustained-release suppositories. Int J Gynaecol Obstet 2000, 71 Suppl 1:S47-52

181. Fian R, Grasser E, Treiber F, Schmidt R, Niederl P, Rosker C: The contribution of TRPV4-mediated calcium signaling to calcium homeostasis in endothelial cells. J Recept Signal Transduct Res 2007, 27(2-3):113-124.

182. Fleming I, Rueben A, Popp R, Fisslthaler B, Schrodt S, Sander A, Haendeler I, Falck JR, Morisseau C, Hammock BD et al: Epoxyeicosatrienoic acids regulate Trp channel dependent Ca2+ signaling and hyperpolarization in endothelial cells. Arterioscler Thromb Vasc Biol 2007, 27(12):2612-2618.

183. Simonin C, Awale M, Brand M, van Deursen R, Schwartz J, Fine M, Kovacs G, Hafliger P, Gyimesi G, Sithampari A et al: Optimization of TRPV6 Calcium Channel Inhibitors Using a 3D Ligand-Based Virtual Screening Method. Angew Chem Int Ed Engl 2015, 54(49):14748-14752.

184. Janssens A, Silvestri C, Martella A, Vanoevelen JM, Di Marzo V, Voets T: Delta(9)-tetrahydrocannabivarin impairs epithelial calcium transport through inhibition of TRPV5 and TRPV6. Pharmacol Res 2018, 136:83-89.

185. De Petrocellis L, Orlando P, Moriello AS, Aviello G, Stott C, Izzo AA, Di Marzo V: Cannabinoid actions at TRPV channels: effects on TRPV3 and TRPV4 and their potential relevance to gastrointestinal inflammation. Acta Physiol (Oxf) 2012, 204(2):255-266.

186. De Petrocellis L, Ligresti A, Moriello AS, Allara M, Bisogno T, Petrosino S, Stott CG, Di Marzo V: Effects of cannabinoids and cannabinoid-enriched Cannabis extracts on TRP channels and endocannabinoid metabolic enzymes. Br J Pharmacol 2011, 163(7):1479-1494.

187. Jiang Y, Gou H, Zhu J, Tian S, Yu L: Lidocaine inhibits the invasion and migration of TRPV6-expressing cancer cells by TRPV6 downregulation. Oncol Lett 2016, 12(2):1164-1170. 